\title{
Mechanism of MSCs Differentiation into Hepatocyte-Like Cells: The Role of Cytokines and Chemical Compounds
}

\author{
Mingying Liu and Yingjie Wang* \\ Institute of infectious disease, Southwest Hospital, Third Military Medical University, China
}

\begin{abstract}
Background: The comprehensive mechanism of MSCs (mesenchymal stem cells) differentiation into hepatocytes is still not clear. Yet it is certain that the growth and differentiation of MSCs are regulated by the interaction of specific extracellular mediators. Meanwhile, various kinds of cytokines and chemical compounds have shown certain effects on hepatocyte differentiation of mesenchymal stem cells, certain mechanism of cytokines and combination of protocol of cytokines has been well explored, while others are remain unclear.
\end{abstract}

Data Sources: A [pub med /Medline] search was performed on the topic of "mesenchymal stem cells", "hepatocytes", "cytokines" and "chemical". The relevant articles published in the past fifteen years were reviewed.

Conclusions: Most adult tissues and organs are derived from the process of mesenchymal to epithelial transition (MET) and its reverse process EMT. Wnt pathways play an important role in switching on the EMT regulatory program. Someof the important cytokines and chemical compounds such as FGFs, BMP and norepinephrine are involved in this pathway. The major cytokines like HGF, EGF and Dexamethas are involved in DNA modification. The formulation of the "optimal" cytokine / growth factor combinations is still at an immature stage of development depending upon sources and types of MSCs.

Keywords: Cytokines; Chemical differentiation; Mesenchymal stem cells

compounds; Hepatocyte

\section{Introduction of MSCs Differentiation into Hepatocyte- Like Cells}

The comprehensive mechanism of MSCs (mesenchymal stem cells) differentiation into hepatocytes is still not clear. Yet it is certain that the growth and differentiation of MSCs are regulated by the interaction of specific extracellular mediators [1]. Most adult tissues and organs are derived from the process of mesenchymal to epithelial transition [MET] and reverse process epithelial to mesenchymal transition EMT (Figure 1) [2]. Epithelial cells are closely connected with their neighbors and apicobasal axis of polarity by order of adherens junctions, desmosomes, while Mesenchymal stromal cells connected with a loose organization of a three-dimensional extracellular matrix. The processes of MET and EMT are essential for embryonic development.

Wnt signaling is one of the most important parts in the process of the MET (Figure 2) [2]. Studies have shown that Wnts signaling pathways and their downstream singling play a significant role in the self-renewal and differentiation of MSCs [3]. Wnt signal is thought to be involved in many animal embryonic development and proliferation of hematopoietic cells, In the process of differentiation of MSCs into hepatocytes, blocking [4] the Wnt signaling pathway can promote the differentiation of MSCs into hepatocytes. In Wnt Norepinephrine excited PCK is [5], which then stimulates G protein, reduce the transient outward $\mathrm{K}+$ current and block the pathway. The activity of Wnts is also influenced by external factors, especially the heparan sulfate proteoglycans. Heparan sulfate chain contains Wnts, BMP, FGF, which are the key factors to control cell growth and development.

DNA modification also contributes to differentiation of MSCs. DNA methyltransferase has been shown to help in differentiation of MSCs, chromatin reorganization is a promising method for induction of MSCs specific differentiation. In this process Oncostatin M (OSM) had been demonstrated that it through gp 130, an OSM receptor subunit, to accelerate maturation of the liver development [6]. Experiments also showed that livers from mice deficient for gp130 displayed defects in maturation of hepatocytes [7]. In vivo OSM carry on a paracrine mechanism of hepatogenesis; blood cells, transiently expanding in the fetal liver. Meanwhile several other mechanisms in DNA modification are shown to be related with the effect of HGF, ras-ERK1/2 MAPK and PI3K/Akt was detected to be associated with HGF mitogenic and morphogenic effects, $\mathrm{p}^{38}$ MAPK seemed to be linked with the arrest of cell proliferation by blocking cells in the G0-G1 phase [8] (Table 1).

\section{Cytokines and Chemical compounds}

In vitro, under the circumstance of being induced by cytokines such as hepatocyte growth factor (HGF), epidermal cell growth factor (EGF), fibroblast growth factor (FGF), OSM, transforming growth factor (TGF), insulin-like growth factor (IGF), bFGF, leukemia inhibitory factory (LIF) and bone morphogenetic protein (BMP), MSCs could be differentiated into hepatocyte like cells [8-16]. Since various kinds of cytokines and chemical compounds have shown certain effects on differentiation of mesenchymal stem cells, certain mechanisms of cytokines and combinations of protocols of cytokines have been well explored, while others are remain unclear.

Hepatocyte growth factor (HGF) serves as a starting signal of liver regeneration [6], HGF involved with the endoderm development in the process of embryonic development. It is a potent mitogen for hepatocyte cloning, and has been considered as a pleiotropic cytokine

*Corresponding author: Yingjie Wang, Institute of Infectious Disease, Southwest Hospital, Third Military Medical University, Chongqing -400038, China, Tel: 8602368765221; E-mail: yingjiewng@yahoo.com

Received January 23, 2014; Accepted March 19, 2014; Published March 21 , 2014

Citation: Liu M, Wang Y (2014) Mechanism of MSCs Differentiation into Hepatocyte-Like Cells: The Role of Cytokines and Chemical Compounds. J Stem Cell Res Ther 4: 179. doi:10.4172/2157-7633.1000179

Copyright: (c) 2014 Liu M, et al. This is an open-access article distributed under the terms of the Creative Commons Attribution License, which permits unrestricted use, distribution, and reproduction in any medium, provided the original author and source are credited. 
Citation: Liu M, Wang Y (2014) Mechanism of MSCs Differentiation into Hepatocyte-Like Cells: The Role of Cytokines and Chemical Compounds. J Stem Cell Res Ther 4: 179. doi:10.4172/2157-7633.1000179

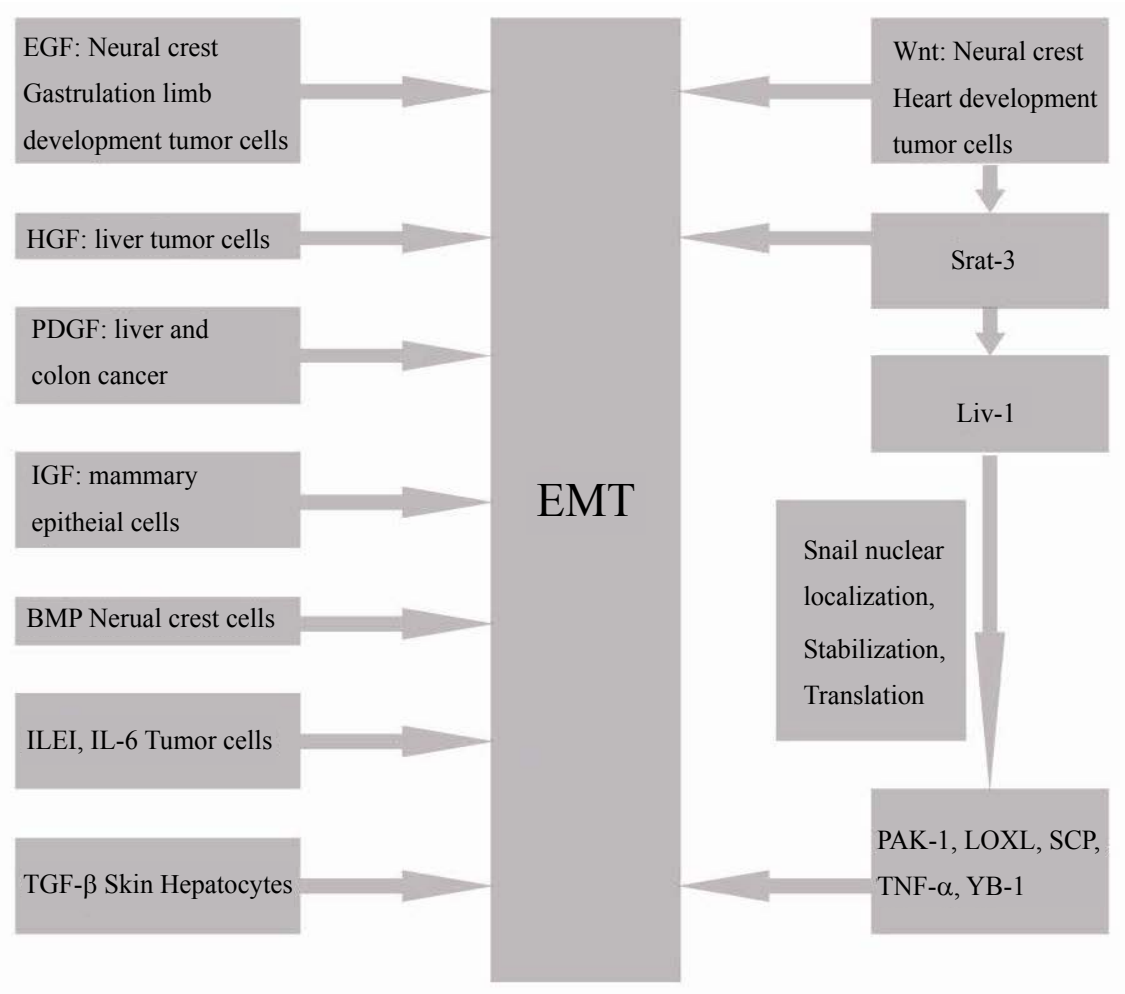

Figure 1: [2] Factors that promotes EMT biological process. Some of these transcription factors are regulated by their sub cellular localization and transcription after proteasome function.

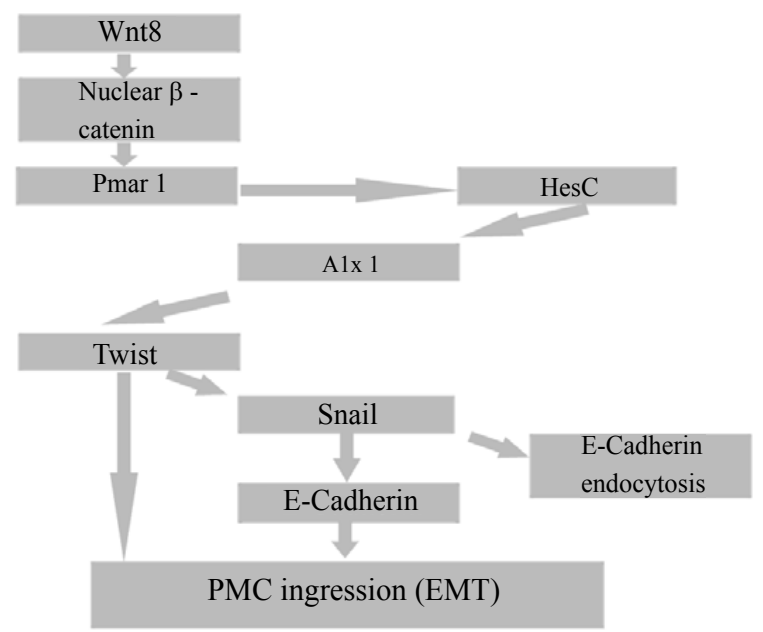

Figure 2: [2] Wnt8 singnaling leads the human embryonic stem cell inhibition, switching on the EMT regulatory program, inducing the ingression of the primary mesenchymal stem cells (PMCs)

for the mesenchymal origin. C-Met is receptor of regulating growth of liver, it is a transmembrane protein, with an intracellular tyrosine kinase domain, and it has stimulating effect in the processes of mitosis and remodeling. When short term exposure to HGF, MSCs can induce its cognate receptor activation of ERK1 / 2, $\mathrm{p}^{38}$, MAPK and PI3K/Akt, while long-term exposure to HGF, MSCs will lead to the cytoskeleton, cell migration, and significantly inhibited in G1-S restriction point multiplication [8], which suggest that HGF may play a different role according to cell's proliferation cycle.
Epidermal cell growth factor (EGF) stimulates ion flow, accelerate glucose transport, glycolysis and increases DNA, RNA and protein synthesis, especially for liver epithelial cells, EGF is a mitogenic factor and combines with membrane receptor EGFR, promoting liver stem cells proliferation [17]. EGF fos family's mRNA showed that the combination between EGF and its receptor EGFR is mainly focused upon PI3K and ERK1/2 signal pathway [10].

Basic fibroblast growth factor (bFGF) belongs to the polypeptide cell 
Citation: Liu M, Wang Y (2014) Mechanism of MSCs Differentiation into Hepatocyte-Like Cells: The Role of Cytokines and Chemical Compounds. J Stem Cell Res Ther 4: 179. doi:10.4172/2157-7633.1000179

Page 3 of 5

\begin{tabular}{|c|c|c|}
\hline $\begin{array}{l}\text { Cytokines/ Chemical } \\
\text { Compounds }\end{array}$ & Possiblemechanism & Reference \\
\hline Norepinephrine & $\begin{array}{l}\text { Wnt signaling pathway: Protein kinase } \mathrm{C}(\mathrm{PKC}) \\
\text { activated, stimulates a G reduce the transient outward } \mathrm{K}+\text { current }\end{array}$ & [3] \\
\hline FGFs,BMP & $\begin{array}{l}\text { Wnt extra cellular factors: heparan sulfate proteoglycans. The polysaccharide chains of heparan sulfate bind to FGFs, } \\
\text { Wnts and BMPs }\end{array}$ & [3] \\
\hline Hepatocyte growth factor (HGF) & $\begin{array}{l}\text { 1. Ras-ERK1/2 MAPK: mitogenic and morphogenic } \\
\text { 2. PI3K/Akt: mitogenic and antiapoptotic } \\
\text { 3. } p^{38 M A P K: ~ b l o c k i n g ~ c e l l s ~ i n ~ t h e ~ G 0-G 1 ~ p h a s e ~}\end{array}$ & [8] \\
\hline Transforming growthfactor- $\beta$ & $\begin{array}{l}\text { Gadd45b promoter activated by TGF- } \beta \\
\text { through theaction of Smad2, Smad3, and Smad4 }\end{array}$ & [9] \\
\hline OSM & gp130 induces gene-expression, followed byparacrine secretion & [7] \\
\hline $\begin{array}{l}\text { Epidermal growthfactor (EGF) } \\
\text { Dexamethasone }\end{array}$ & Lead to ERK1/2 phosphorylation & [10] \\
\hline $\begin{array}{l}\text { Granulocyte macrophage colony } \\
\text { stimulating factor } \\
\text { (GM-CSF) }\end{array}$ & Induction of suppressor leukocytes: iNOS, T cell CD3- $\delta$ & [11] \\
\hline $\begin{array}{l}\text { Stromal } \\
\text { derived }\end{array}$ & $\begin{array}{l}\text { Ligand for the chemokine receptor CXCR4. } \\
\text { CXCR4-mediated signaling regulates cell }\end{array}$ & [12] \\
\hline factor-1a (SDF-1a) & migration and apoptosis & \\
\hline Retinoic acid & $\begin{array}{l}\text { Acting through RARY up-regulation of hepatic CB1R mediates the autoinduction of CB1R expression by endo } \\
\text { cannabinoids }\end{array}$ & [13] \\
\hline Sodium butyrate & $\begin{array}{l}\text { 1. Promotes protein acetylation at targets : } \mathrm{H} 3 \mathrm{~K} 9 \\
\text { 2. Accelerates promoter DNA demethylation, expression of pluripotency-associated genes: POU5F1/OCT4 and } \\
\text { DPPA2 }\end{array}$ & [14] \\
\hline Dimethyl sulfoxide & Decreases membrane thickening, inducingapoptosis and differentiation & [15] \\
\hline
\end{tabular}

Table 1: Possible Mechanism of cytokines/ chemical compounds.

\begin{tabular}{|c|l|l|}
\hline Source/species & Differentiation protocol & Hepatocyte specific markers/functions \\
\hline r-MSC & FGF-4+HGF+ITS+Dexa & AFP, HNF3, HNF1,CK18,ALB \\
\hline r-MSC & MSC+HGF+CNP & AFP, CK18,CK19 \\
\hline r-MSC & HGF+EGF+ Dexa & CK19, AFP, DPP IViNOS \\
\hline h-MSC & $\begin{array}{l}\text { MACS sortedCD105+ATMSCs/ HGF+FGF1+ } \\
\text { FGF4 /OSM+Dexa }\end{array}$ & $\begin{array}{l}\text { ALB, AFP, TTR, HNF-4,TDO2, CK18, TTR, ammonia } \\
\text { detoxification, PAS staining, LDL-uptake }\end{array}$ \\
\hline h-MSC & HGF+bFGF+ nicotinamide+OSM+Dexa & CK-18, CK-19, ALB,TTR, CYP2E1, EBP 3 \\
\hline h-MSC & EGF+FGF2 / HGF+FGF2+nicotinamide / OSM+ Dexa & $\begin{array}{l}\text { AFP,ALB, CK18, TAT,TDO2, G6P, HNF-4, urea synthesis, CYP } \\
\text { activity. LDL-uptake, PASstaining }\end{array}$ \\
\hline h-MSC & HGF+OSM+Dexa+ nicotinamide [34] & $\begin{array}{l}\text { AFP, CK18,ALB, TDO2,TAT,AAT, HNF-4, urea synthesis, PAS } \\
\text { staining, CYP activity }\end{array}$ \\
\hline h-MSC & OSM+TSA+DMSO & CK18, a-FP, a-SMA \\
\hline
\end{tabular}

Table 2: Differentiation protocol of MSCs towards Hepatocyte-Like Cells.

growth factors and is a broad-spectrum mitogen, it play an important role in embryonic development and cell proliferation, especially for those who derive from mesoderm and ectoderm [18], When bFGF was intravenous injected into rats, their osteogenic precursor cells were significantly increased and new bone formation improved [19].

Fibroblast growth factor-4 (FGF-4) can induce the cells to differentiate into hepatocytes and then express their related genes [20]. It shows that FGF- 4 effect upon cell initial stage and endoderm parts [21].

Interleukin 6 (IL-6) not only serves as important molecule start liver regeneration [22], but also activates cell signal transduction system $[23,24]$ when mice whose IL-6 gene were knockout were found out that the regeneration ability of its liver were reduced, meanwhile the injection of IL-6 can restore DNA replication and STAT3's activity [25].

Oncostatin M (OSM) is a subfamily member of IL-6, it restrain the activity of A375 melanoma cells, OSM is capable of stimulating maturation of hepatic parenchymal cells and of terminating embryonic liver function [26]. Leukemia inhibitory factor (LIF) is another member of IL-6, which involve in the acquisition of hepatocyte features in BMMSCs like protein and gene expression of hepatic markers [27]. Bone morphogenetic protein (BMP) involved in cell's regulation of growth, reproduction, differentiation, and apoptosis $[28,29]$. The BMP-2, 7play a key role in inducing MSCs expressing the transcription factors Runx2 and Osterix, The process is irreversible, yet no evidence had been showed that BMPs have biological effects on mature cells.

Another important chemical compound is dexamethasone (Dexa), which induces the expression of nuclear factor of 4 and CCAAT / enhancer -binding protein alpha [30], these two factors belong to hepatocyte nuclear factors and are the crucial transcription factors for hepatocyte differentiation. Dexa inhibits the expression of hepatocyte growth inhibitory molecules such as CXC chemokine receptor, amphiregulin, cyclooxygenase 2, and hypoxia inducible factor. Nor epinephrine (NE) is another important chemical compound, experiment show that NE at $10^{-6}-10^{-4} \mathrm{~mol} / \mathrm{L}$ and cultured $8 \mathrm{~h}$ could promote BMSCs cell growth, the proliferation rate increased 5\%, 37\% and $10 \%$, its mechanism involve protein kinase $\mathrm{C}$ (PKC) [5] was excited and then translocated from cytosolic to membrane, there are two types of isomers of PCK, PCK $\delta$ and PCK $\lambda$, their distribution are various according to different animals, even in a single cell their amount, activation and function are different depend upon cell's physiological stages. It is still unknown who type of PCK are increasingly important.

\section{Formulation of optimal combinations}

Of all of these cytokines and growth factors, HGF, EGF, TGF and 
Citation: Liu M, Wang Y (2014) Mechanism of MSCs Differentiation into Hepatocyte-Like Cells: The Role of Cytokines and Chemical Compounds. J Stem Cell Res Ther 4: 179. doi:10.4172/2157-7633.1000179

Page 4 of 5

aFGF are the most cytokines used for researching [31-33] for any certain cytokines or growth factor, it is important to note differences in the different stage of MSCs development and different species/source of MSCs [34], The optimal cytokine stimulation, dosage, time and combination for the differentiation of MSCs should be well organized according to the stem cell sources and types (such as ES cells, bone marrow mesenchymal stem cells or hepatic stem cells). While the formulation of the "optimal" cytokine / growth factor combinations is still at an immature stage of development (Table 2).

While [40] using the combined exposure to FGF + HGF + ITS + DEX to transform multipotent adult progenitor cells (MAPCs) into hepatocytes, yet the result are less ideal. Several researchers added a mixture of FGF + HGF [41-43] or of FGF + HGF + OSM [38] according to distinctive hepatocyte markers such as albumin and urea secretion, glycogen storage, and low-density lipoprotein, while others put emphasis on hepatic function conversion by adding inducing factors [44], the synergistical effects of DEX, ITS, and nicotinamide are mainly focus upon driving the singling pathways [45], Itseems that the optimized differentiation is gained from the same hepatogenic factors [34].

Another consideration is the approach of adding factors, More than $85 \%$ of sequentially cultured cells phenotype express highly differentiated hepatocytes, including induction of cytochrome P450 (CYP) - dependent activity, When compare the approach of sequential exposure and cocktail exposure to liver-specific factors, the latter result shows more obvious and homogeneous BMSC differentiation into functional hepatocyte like cells can be gained through sequential differentiation process [35]. Also the dosage of and growth factors and cytokines should be fine-tuned in vitro, usually $0-60 \mathrm{ng} / \mathrm{mL}$ for EGF and FGF, 0-30ng/mL for HGF and OSM, according to type of combination[46].

\section{Conclusion}

Over the last decade, various studies have suggested that the effects cytokines and chemical compounds are the major contributor for the differentiation of mesenchymal stem cells towards to hepatocyte like cells; current research suggests that most adult tissues and organs are derived from the process of mesenchymal to epithelial transition MET and its reversible process EMT. In which the Wnt pathways play an important role in switching on the EMT regulatory program. Some of the important cytokines and chemical compounds such as FGFs, BMP and norepinephrin are involve in this pathway. The major cytokines like HGF, EGF and Dexamethas are involved in DNA modification. The HGF, EGF, TGF and aFGF used for combination, while the formulation of the "optimal" cytokine / growth factor combinations is still at an immature stage of development depend upon sources and types of MSCs.

\section{Acknowledgements}

This study was supported by grants from the National Natural Science Foundation of China (grant No. 31070880 and grant No. 81270524).

\section{References}

1. Wu XB, Tao R (2012) Hepatocyte differentiation of mesenchymal stem cells. Hepatobiliary Pancreat Dis Int 11(4): 360-371. [PubMed]

2. Thiery JP, Acloque H, Huang RY, Nieto MA (2009) Epithelial-mesenchymal transitions in development and disease. Cell 139(5): 871-890. [PubMed]

3. Ling L, Nurcombe V, Cool SM (2009) Wnt signaling controls the fate of mesenchymal stem cells. Gene 433(1-2): 1-7. [PubMed]

4. Ke Z, Zhou F, Wang L, Chen S, Liu F, et al. (2008) Down-regulation of Wnt signaling could promote bone marrow-derived mesenchymal stem cells to differentiate into hepatocytes. Biochem Biophys Res Commun 367(2): 342 348. [PubMed].

5. Gallego M, Setien R, Puebla L, Boyano-Adanez Mdel C, Arilla E, et al. (2005) alpha1-Adrenoceptors stimulate a Galphas protein and reduce the transien outward K+ current via a cAMP/PKA-mediated pathway in the rat heart. Am J Physiol Cell Physiol 288(3): C577-C585? [PubMed]

6. Kinoshita T, Hirao S, Matsumoto K, Nakamura T (1991) Possible endocrine control by hepatocyte growth factor of liver regeneration after partial hepatectomy. Biochem Biophys Res Commun 177(1): 330-335. [PubMed]

7. Kamiya A, Kinoshita T, Ito Y, Matsui T, Morikawa Y, et al. (1999) Fetal liver development requires a paracrine action of oncostatin $M$ through the gp130 signal transducer. EMBO J 18(8): 2127-2136. [PubMed]

8. Forte G, Minieri M, Cossa P, Antenucci D, Sala M, et al. (2006) Hepatocyte growth factor effects on mesenchymal stem cells: proliferation, migration, and differentiation. Stem Cells 24(1): 23-33. [PubMed]

9. Yoo J, Ghiassi M, Jirmanova L, Balliet AG, Hoffman B, et al. (2003) Transforming growth factor-beta-induced apoptosis is mediated by Smaddependent expression of GADD45b through p38 activation. J Biol Chem 278(44): 43001-43007. [PubMed]

10. Li B, Du T, Li H, Gu L, Zhang H, et al. (2008) Signalling pathways for transactivation by dexmedetomidine of epidermal growth factor receptors in astrocytes and its paracrine effect on neurons. Br J Pharmacol 154(1): 191 203. [PubMed]

11. Yen BL, Yen ML, Hsu PJ, Liu KJ, Wang CJ, et al. (2013) Multipotent Human Mesenchymal Stromal Cells Mediate Expansion of Myeloid-Derived Suppressor Cells via Hepatocyte Growth Factor/c-Met and STAT3. Stem Cell Reports 1(2): 139-151. [PubMed]

12. Jaleel MA, Tsai AC, Sarkar S, Freedman PV, Rubin LP (2004) Stromal cellderived factor-1 (SDF-1) signalling regulates human placental trophoblast cell survival. Mol Hum Reprod 10(12): 901-909. [PubMed]

13. Mukhopadhyay B, Liu J, Osei-Hyiaman D, Godlewski G, Mukhopadhyay P, et al. (2010) Transcriptional regulation of cannabinoid receptor-1 expression in the liver by retinoic acid acting via retinoic acid receptor-gamma. J Biol Chem 285(25): 19002-19011. [PubMed]

14. Mali P, Chou BK, Yen J, Ye Z, Zou J, et al. (2010) Butyrate greatly enhances derivation of human induced pluripotent stem cells by promoting epigenetic remodeling and the expression of pluripotency-associated genes. Stem Cells 28(4): 713-720. [PubMed]

15. Stolzing A, Naaldijk Y, Fedorova V, Sethe S (2012) Hydroxyethylstarch in cryopreservation - mechanisms, benefits and problems. Transfus Apher Sci 46(2): 137-147. [PubMed]

16. Taléns-Visconti R, Bonora A, Jover R, Mirabet V, Carbonell F, et al. (2007) Human mesenchymal stem cells from adipose tissue: Differentiation into hepatic lineage. Toxicol In Vitro 21(2): 324-329. [PubMed]

17. Isfort RJ, Cody DB, Richards WG, Yoder BK, Wilkinson JE, et al. (1998) Characterization of growth factor responsiveness and alterations in growth factor homeostasis involved in the tumorigenic conversion of mouse oval cells. Growth Factors 15(2): 81-94. [PubMed]

18. Hughes SE, Hall PA (1993) The fibroblast growth factor and receptor multigene families. J Pathol 170(3): 219-221. [PubMed]

19. Nakamura T, Hanada K, Tamura M, Shibanushi T, Nigi H, et al. (1995) Stimulation of endosteal bone formation by systemic injections of recombinan basic fibroblast growth factor in rats. Endocrinology 136(3): 1276-1284. [PubMed]

20. Ruhnke M, Ungefroren H, Zehle G, Bader M, Kremer B, et al. (2003) Long-term culture and differentiation of rat embryonic stem cell-like cells into neuronal, glial, endothelial, and hepatic lineages. Stem Cells 21(4): 428-436. [PubMed]

21. Chivu M, Dima SO, Stancu Cl, Dobrea C, Uscatescu V, et al. (2009) In vitro hepatic differentiation of human bone marrow mesenchymal stem cells under differential exposure to liver-specific factors. Transl Res 154(3): 122-132. [PubMed]

22. Ramadori G, Armbrust T (2001) Cytokines in the liver. Eur J Gastroenterol Hepatol 13(7): 777-784.[PubMed]

23. Sánchez A, Factor VM, Schroeder IS, Nagy P, Thorgeirsson SS (2004) Activation of NF-kappaB and STAT3 in rat oval cells during 2-acetylaminofluorene/partial hepatectomy-induced liver regeneration. Hepatology 39(2): 376-385. [PubMed] 
Citation: Liu M, Wang Y (2014) Mechanism of MSCs Differentiation into Hepatocyte-Like Cells: The Role of Cytokines and Chemical Compounds. J Stem Cell Res Ther 4: 179. doi:10.4172/2157-7633.1000179

Page 5 of 5

24. Akhurst B, Matthews V, Husk K, Smyth MJ, Abraham LJ, et al. (2005) Differential lymphotoxin-beta and interferon gamma signaling during mouse liver regeneration induced by chronic and acute injury. Hepatology 41(2): $327-$ 335. [PubMed]

25. Galun E, Zeira E, Pappo O, Peters M, Rose-John S (2000) Liver regeneration induced by a designer human IL-6/sIL-6R fusion protein reverses severe hepatocellular injury. FASEB J 14: 1979-1987. [PubMed]

26. Kinoshita T1, Sekiguchi T, Xu MJ, Ito Y, Kamiya A, et al. (1999) Hepatic differentiation induced by oncostatin $M$ attenuates fetal liver hematopoiesis. Proc Natl Acad Sci U S A 96(13): 7265-7270. [PubMed]

27. Lysy PA, Smets F, Najimi M, Sokal EM (2008) Leukemia inhibitory factor contributes to hepatocyte-like differentiation of human bone marrow mesenchymal stem cells. Differentiation 76(10): 1057-1067. [PubMed]

28. Chen D, Zhao M, Mundy GR (2004) Bone morphogenetic proteins. Growth Factors 22(4): 233-241. [PubMed]

29. Kugimiya F, Ohba S, Nakamura K, Kawaguchi H, Chung UI (2006) Physiological role of bone morphogenetic proteins in osteogenesis. J Bone Miner Metab 24(2): 95-99. [PubMed]

30. Michalopoulos GK, Bowen WC, Mulè K, Luo J (2003) HGF-, EGF-, and dexamethasone-induced gene expression patterns during formation of tissue in hepatic organoid cultures. Gene Expr 11(2): 55-75. [PubMed]

31. Hu A, Cai J, Zheng Q, He X, Pan Y, et al. (2003) Hepatic differentiation from embryonic stem cells in vitro. Chin Med J (Engl) 116(12): 1893-1897. [PubMed]

32. Michalopoulos GK, Bowen WC, Mulè K, Luo J (2003) HGF-, EGF-, and dexamethasone-induced gene expression patterns during formation of tissue in hepatic organoid cultures. Gene Expr 11(2): 55-75. [PubMed]

33. Block GD, Locker J, Bowen WC, Petersen BE, Katyal S, et al. (1996) Population expansion, clonal growth, and specific differentiation patterns in primary cultures of hepatocytes induced by HGF/SF, EGF and TGF alpha in a chemically defined (HGM) medium. J Cell Biol 132(6): 1133-1149. [PubMed]

34. Banas A, Yamamoto Y, Teratani T, Ochiya T (2007) Stem cell plasticity: learning from hepatogenic differentiation strategies. Dev Dyn 236(12): 32283241. [PubMed]

35. Snykers S, Vanhaecke T, Papeleu P, Luttun A, Jiang Y, et al. (2006) Sequential exposure to cytokines reflecting embryogenesis: the key for in vitro differentiation of adult bone marrow stem cells into functional hepatocyte-like cells. Toxicol Sci 94(2): 330-341. [PubMed]
36. Pulavendran S, Rose C, Mandal AB (2011) Hepatocyte growth factor incorporated chitosan nanoparticles augment the differentiation of stem cell into hepatocytes for the recovery of liver cirrhosis in mice. J Nanobiotechnology 9: 15. [PubMed]

37. Lee KD, Kuo TK, Whang-Peng J, Chung YF, Lin CT, et al. (2004) In vitro hepatic differentiation of human mesenchymal stem cells. Hepatology $40(6)$ 1275-1284. [PubMed]

38. Ong SY, Dai H, Leong KW (2006) Hepatic differentiation potential of commercially available human mesenchymal stem cells. Tissue Eng 12(12): 3477-3485. [PubMed]

39. Yoon HH, Jung BY, Seo YK, Song KY, Park JK (2010) In vitro hepatic differentiation of umbilical cord-derived mesenchymal stem cell. Process Biochemistry 45: 1857-1864. [ScienceDirect]

40. Schwartz RE, Reyes M, Koodie L, Jiang Y, Blackstad M, et al. (2002) Multipotent adult progenitor cells from bone marrow differentiate into functional hepatocytelike cells. J Clin Invest 109(10): 1291-1302. [PubMed]

41. Kang XQ, Zang WJ, Bao LJ, Li DL, Song TS, et al. (2005) Fibroblast growth factor- 4 and hepatocyte growth factor induce differentiation of human umbilical cord blood-derived mesenchymal stem cells into hepatocytes. World J Gastroenterol 11(47): 7461-7465. [PubMed]

42. Shu SN, Wei L, Wang JH, Zhan YT, Chen HS, et al. (2004) Hepatic differentiation capability of rat bone marrow-derived mesenchymal stem cells and hematopoietic stem cells. World J Gastroenterol 10(19): 2818-2822. [PubMed]

43. Shi XL, Quu YD, Wu XY, Xie T, Zhu ZH, et al. (2005) In vitro differentiation of mouse bone marrow mononuclear cells into hepatocyte-like cells. Hepatol Res 31(4): 223-231. [PubMed]

44. Lange C, Bassler P, Lioznov MV, Bruns H, Kluth D, et al. (2005) Hepatocytic gene expression in cultured rat mesenchymal stem cells. Transplant Proc 37(1): 276-279. [PubMed]

45. Seo MJ, Suh SY, Bae YC, Jung JS (2005) Differentiation of human adipose stromal cells into hepatic lineage in vitro and in vivo. Biochem Biophys Res Commun 328(1): 258-264. [PubMed]

46. Snykers S, De Kock J, Rogiers V, Vanhaecke T (2009) In vitro differentiation of embryonic and adult stem cells into hepatocytes: state of the art. Stem Cells 27(3): 577-605. [PubMed] 